\title{
LOW IMPACT DEVELOPMENT MODELING TO MANAGE URBAN STORMWATER RUNOFF: CASE STUDY OF GORZÓW WIELKOPOLSKI
}

\author{
Ireneusz NOWOGOŃSKI (®* \\ Faculty of Civil Engineering, Architecture and Environmental Engineering, University of Zielona Góra, Poland
}

Received 26 July 2019; accepted 19 February 2020

\author{
Highlights \\ - LID may not be effective for overloaded systems; \\ - reducing flow rate in drainage allows to reduce the volume of local flooding; \\ the use of LID is definitely more effective than classic solutions; \\ - LID ought to be implemented synchronically with classical solutions.
}

\begin{abstract}
Uncontrolled urbanization causes local flooding and deterioration of the water quality of receivers as a result of an increase in peak flow rate and increased washing out of contaminants from the catchment area. Currently, classic storage tanks are most often used. An alternative solution may be the use of Low Impact Development (LID), i.e. the preservation and restoration of natural landscape elements, minimizing the imperviousness of the catchment in the form of rain barrels, permeable walkways or bio-retention reservoirs. The comparison of both techniques was carried out using the Environmental Protection Agency Storm Water Management Model (EPA SWMM). The influence of several solutions on a selected urbanized catchment located in Gorzów Wielkopolski was tested.
\end{abstract}

Keywords: drainage, local flooding, low impact development (LID) practices, modelling, runoff, storm water, SWMM.

\section{Introduction}

The increasing share of non-permeable terrain in urban areas causes significant changes in the land properties. The reach of native vegetation is limited, and resources of shallow natural soil depressions, which allow for intercepting, storing and infiltrating rainwater, are decreased. The effect is an increase in the speed and volume of runoff, while limiting evapotranspiration and interception (Palla \& Gnecco, 2015). As a result, the observed changes pertain to an increase in peak flows, limiting the time of concentration, changes in the water balance and sudden flows in rivers and in other watercourses in the area of an urban catchment (Eckart et al., 2018). Other factors necessitating the implementation of new solutions in managing rainwater are climatic changes (Berndtsson et al., 2019) and changes in legal regulations in the scope of environmental management. In many large cities throughout the world, LID methods have been introduced for planning the management of wastewaters (Eckart et al., 2017). Lowimpact development (LID) is a term used in Canada and the United States to describe a land planning and engineering design approach to manage stormwater runoff as part of green infrastructure. One of the most important principles of LID is introducing new concepts, technologies, and objectives for stormwater management such as micromanagement and multifunctional landscape features (bioretention areas, swales, and conservation areas); mimic or replicate hydrologic functions; and maintain the ecological/biological integrity of receiving streams (Coffman et al., 1999). Other countries have similar approaches in place using a different terminology such as sustainable drainage systems (SuDS) in the UK, and water-sensitive urban design in Australia (Fletcher et al., 2015). The benefits to the community of using SuDS (LID) are numerous, including (Woods-Ballard et al., 2015):

- protecting people and property from increased flood risk resulting from the development;

- protecting the quality of groundwater and surface waters from polluted runoff from the development;

- protecting natural flow regimes in rivers, lakes and streams;

${ }^{*}$ Corresponding author. E-mail: i.nowogonski@iis.uz.zgora.pl 
- supporting local natural habitats and associated ecosystems by encouraging greater biodiversity and linking habitats;

- improving soil moisture and replenishing depleted groundwater levels;

- providing society with a valuable supply of water;

- creating attractive places where people want to live, work and play through the integration of water and green spaces with the built environment;

- improving people's understanding of how runoff from their development is being managed and used;

- supporting the creation of developments that are more able to cope with changes of climate;

- delivering cost-effective infrastructure that uses fewer natural resources than conventional drainage.

On the basis of thus-far realized studies, a thesis can be drawn that benefits connected with applying LID, such as decreasing runoff, or limiting and delaying peak flow intensity are realistic. However, LID cannot be treated in the majority of cases as the only method of returning the state of the catchment to the conditions prior to the urbanization of the land.

The scope of benefits depends on many factors, including many properties dependent on the location and environmental factors. LID indicates high effectiveness in the case of phenomena with a high frequency of occurrence in an analyzed time period. In the case of larger scale events, LID techniques fare best in connection with traditional solutions of managing rainwater, such as retention tanks (Eckart et al., 2017) or as an element of a comprehensive solution like "sponge city" (Mao et al., 2017; Li et al., 2019). Damodaram et al. (2010) confirmed that the conventional approach to the assessment of strategies for managing rainwaters make use of typical sets of classical model rainfall series (e.g. two-year rainfalls). The analysis showed that the range of the applied model rainfalls should be extended to include rainfalls with lower intensity, in order to properly assess the influence of classical solutions and LID technologies. The optimal range covers rainfalls from a six-month up to two-year (Zimmer et al., 2007).
Liu, Bralts, and Engel (2015) presented an analysis based on 15 scenarios of LID implementation. The reduction of the volume of the runoff in best case scenarios can reach as much as $16.47 \%$. This, however, is connected with significant, total costs of realization. Joksimovic and Alam (2014) carried out a simulation by applying six types of LID: a green roof, permeable pavement, infiltration trench, bioretention cell, vegetative swale and rain water harvesting, as well as 11 such combinations. The carried out analysis made it possible to indicate the collection of rainwater (directly on the properties) as requiring the lowest costs and showing the highest economic efficiency (cost recalculated for $1 \mathrm{~m}^{3}$ of a decrease in runoff into the sewage system). The yearly costs of the optimal solution are also confirmed by analyses in the case of catchments located in densely built-up urban areas (Huang et al., 2018). In this case, one of the best solutions also includes collecting rainwater in rain barrels.

The best results were obtained in the case of objects or housing districts designed, from the onset, as ecologi$\mathrm{cal}$, focused on the sustainable management of media (Jia et al., 2012). In the case of providing utilities to existing housing development, such optimistic results are not always guaranteed. Satisfactory results can be obtained in the case of the possibility to make use of using large roofs, such as those of shopping centers, multi-level parking structures (Bąk, 2018) or public utility buildings (Mrowiec \& Sobczyk, 2014). Investments carried out in developed areas, usually difficult to accept by the inhabitants, are an interim solution, and the effects of the introduced changes can be noticed for many years. Figure 1 shows an example of improperly realized drainage of a periodically flooded terrain using a drainage system. The collected water is taken away into stormwater sewage system, and water from waterworks was used to water greenery during periods lacking rainfall (Shuttleworth et al., 2017). Due to the costs, over time, irrigation was carried out less and less frequently, with the consequences visible to the naked eye.

There are currently many hydrological models available, such as: SCS (Soil Conservation Service), SWAT (Soil-Water Assessment Tool), MOUSE (Model of Urban

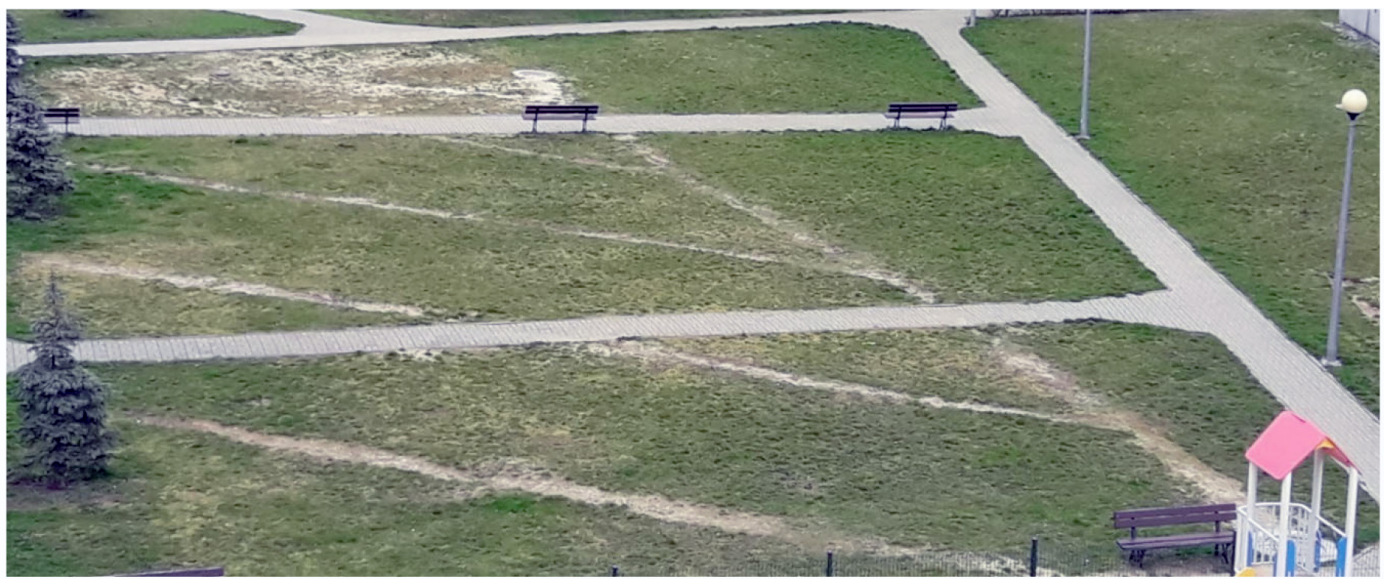

Figure 1. Example of the effects of implementing classical land drainage solution 
Sewers, Danish Hydraulic Institute, 1995), Hydro CAD and the Stormwater Management Model (SWMM) (Kong et al., 2017). Bosley (2008) carried out a sensitivity analysis for 19 of the most frequently used hydrological models or computer programs for an identical area of comparison; it was found that the SWMM was the most appropriate hydrological model to apply in urban areas for various scenarios of land development and the implementation of LID techniques. It was pointed out that in the case of SWMM it is easier to achieve meaningful simulation results based on a short term monitoring program (Bosley, 2008; Palla \& Gnecco, 2015; Granata et al., 2016). SWMM Extran for sewer routing has capabilities similar to commercial software, and contains modules for urban hydrology, real time control systems, and water quality. Most of the program's shortcomings can be eliminated by an intermediate programmer using freeware $\mathrm{C}++$ compiler.

In order to simulate the sewerage system along with the rainwater catchments, the SWMM model is therefore often used, both in the case of a stormwater drainage system and combined sewage system (Nowogoński \& Ogiołda, 2018). Although SWMM includes numerous parameters, those representing LID implementation are limited. For example, the module for calculating vegetative swale includes only storage depth, vegetation volume, surface roughness, surface slope and swale side slope, but does not include such the number and gap of water inlets, the location of overflow gates, the vegetative state, and so on (Rossman, 2015). The limitations of LID routing in SWMM, which prevent routing from one LID to another, might limit the performance of the LID controls. Additionally, none of the scenarios include a full range of possible LID measures, or any combinations with any other stormwater best management practices (Eckart et al., 2018). Due to the limited implementation of LID techniques in the SWMM model, there is a necessity in some cases of applying additional algorithms enabling the optimization of solutions and acceleration of simulation calculations (Zhu et al., 2019).

It should be considered whether the optimistic assumptions of using LID will be true for existing systems. This problem becomes significant, especially in the case of hydraulically overloaded systems (Zhu \& Chen, 2017). Thus, in this study, an analysis was carried out covering both the use of LID and typical solutions.

The use of LID is the recommended and effective solution for restoring the natural circulation of water in the environment. However, it is not a remedy for protection against urban floods. While in the case of newly designed systems efficiency is highly probable, in the case of existing systems, overloaded, the situation is not so simple. In all cases, performance analysis should be performed using modeling. If the security is insufficient, the implementation of classic solutions, such as retention or outflow delay in the channel network should be considered.

\section{Materials and methodology}

As a modelling tool for the described studies, the EPA (SWMM) model of managing stormwater was chosen. SWMM was developed, above all, for urban areas, enabling the simulation of short- and long-term quantity and quality of water (Rossman, 2015). Conceptually speaking, catchments in the SWMM are treated as non-linear tanks, which receive inflows from rainfalls and bordering catchments, generating various outflow components and losses, such as: surface runoff, infiltration and evaporation. The surface retention represented by: ponding, surface wetting and interception described the capacity of these tanks (Krebs et al., 2014). This capacity is defined in SWMM by retention capacity (depression storage) and surface runoff, and is generated only when the depth of the water in the area of the catchment exceeds the indicated storage depth. This runoff is calculated suing Manning's equation.

Catchments can be divided into permeable and nonpermeable subcatchments (defined by the parameter of non-permeability), with individual parameters (such as the retention capacity or Manning's n coefficient for the surface flow) ascribed to each subcatchment. While the available surface of the water on the entire surface of the catchment is subjected to evaporation, infiltration occurs only for water in the permeable subcatchment (Rossman, 2015). In the described studies, the dynamic wave method was used as a model for calculating flow, while infiltration from permeable subcatchments was estimated using Horton's method.

The following issues decided on the selection of an example catchment area:

- local floodings occurs even in the case of low intensity rainfall;

- infiltration-based LID cannot be used due to ground conditions;

- existing buildings and land development enable the implementation of simple storm water harvesting systems (Mao et al., 2017).

The calculation sample was realized based on the calibrated simulation model of a selected stormwater drainage subsystem along with the stormwater catchment. The model was implemented in 2016 and calibrated by a commercial company. Measurement data obtained during the measurement campaign conducted in 2016 and 2017 was used in the model calibration and verification process. The user of the sewerage system - The Gorzów Wielkopolski City Council - uses the model to plan its modernization. Relief is currently being carried out, accounting for the construction of retention reservoirs, modernization of the existing retention-absorption reservoir as well as organization of the drainage network. Total catchment area covers $68.5 \mathrm{ha}$. The impervious area was estimated as 35 ha.

The model developed in the current issue is based on (Figure 2):

- Nodes - 190 nodes and 2 outfalls;

- Sections - 189 channel sections;

- Rainwater catchments - 140 catchments; 


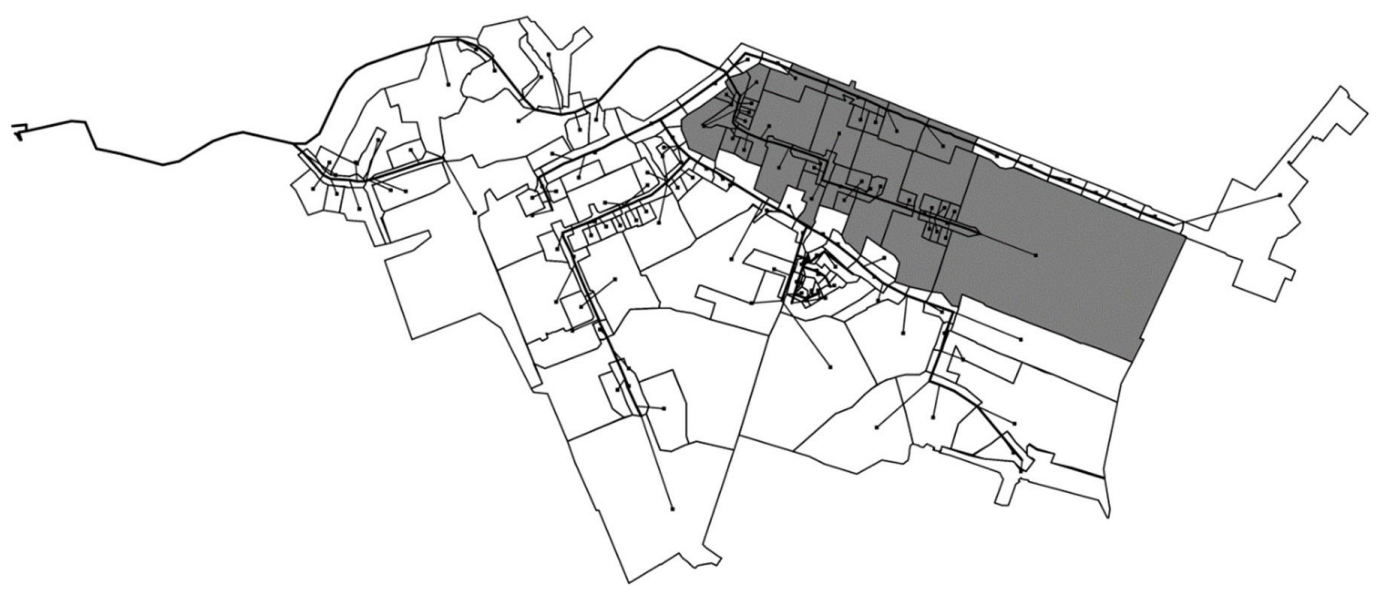

Figure 2. Scheme of existing stormwater drainage system and rainwater catchments connected to junctions

- Time series of rainfall volumes in 5-minute periods for selected phenomena from the years 2011-2015, as well as modelled rainfalls.

The inventory check of the sewerage network allowed for a series of problems, which are the reason behind operational problems, to be confirmed. The main of these include (Figure 3):

- absurd concentration of inspection wells in the middle part of the profile stemming from the necessity of ensuring the possibility of connecting each of the buildings in terraced house development;

- channels laid with an adverse slope.

As of currently, the implementation of the following modernization solutions making it possible to delay the runoff of rainwater have been proposed:

- retention tank with an active capacity of $320 \mathrm{~m}^{3}$;

- retention tank with an active capacity of $460 \mathrm{~m}^{3}$, including $100 \mathrm{~m}^{3}$ pre-treated effluents with a water uptake point from for municipal purposes;

- modernization of the existing retention tank with an active capacity of $3640 \mathrm{~m}^{3}$, including $100 \mathrm{~m}^{3}$ pre- treated sewage with the water uptake point for municipal purposes;

- constructing a bypass channel;

- recreating channels laid out with an adverse slope.

The listed works are currently being implemented, and within the next two years, the assessment of the designed modernization works will be possible. This does not change the fact that the proposed solutions are characterized by a classical approach to managing rainwater. The analyzed catchments have a much higher potential, which can be used when applying even simple LID techniques.

In the analyzed case, the following calculation variants were accounted for:

- the existing system described by a calibrated simulation model;

- a system equipped with reservoirs storing water from the roofs of buildings located in selected stormwater catchments;

- a system modernized based on the described elements accounting for the classical retention structures (Figure 4);

Water Elevation Profile: Node 1_VI_055 - 1_VI_003

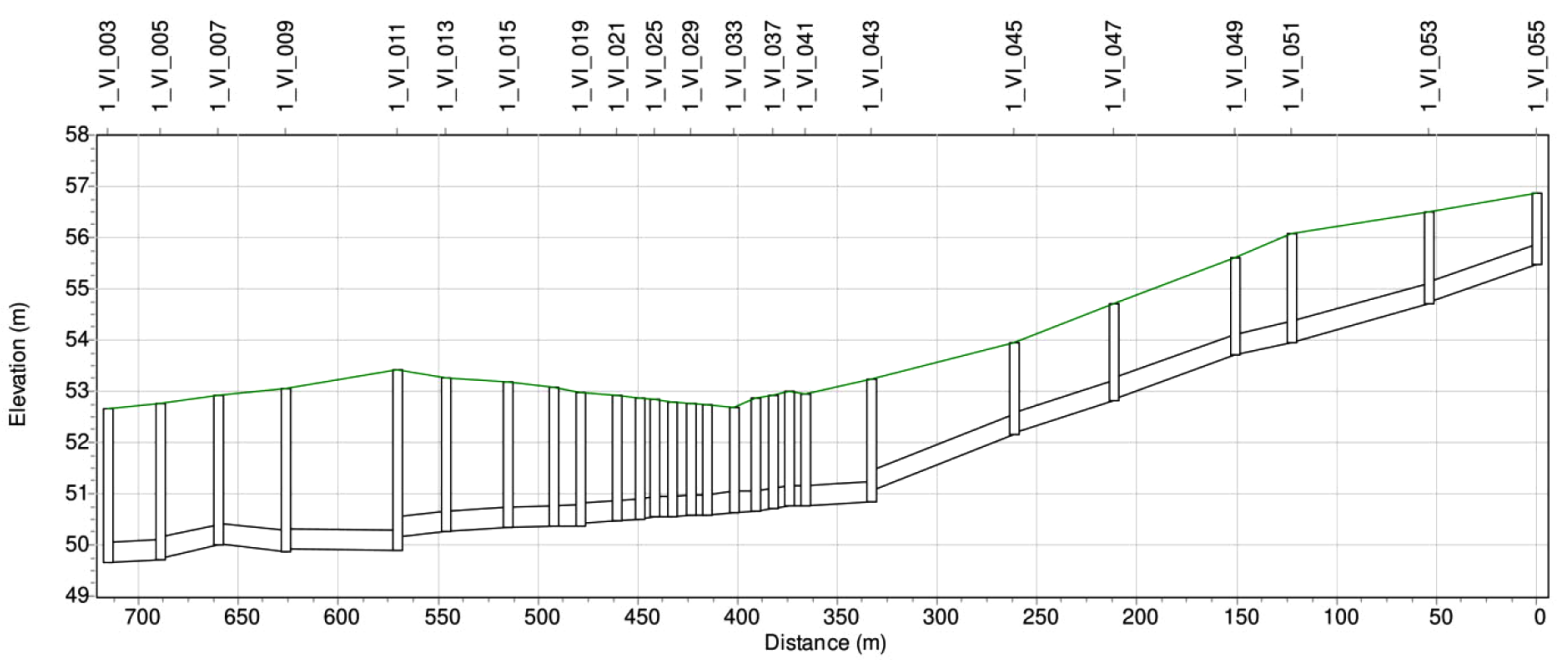

Figure 3. Profile of channel VI in Szarych Szeregów St. 
- a system modernized based on the mentioned elements accounting for classic retention structures and equipped with reservoirs storing water from roofs of buildings located selected stormwater catchments.

For each design variant, calculations were made for a frequency of 2, 35 and 10 years and duration 45 minutes.

The analysis was carried out based on Euler Type II rainfalls with a frequency of occurrence $\mathrm{F}=2, \mathrm{~F}=3, \mathrm{~F}=$ 5 and $\mathrm{F}=10$ years. Model rainfalls with a duration time of $\mathrm{t}=45 \mathrm{~min}$., at a flow time in the network of under 20 min., were applied in the work (Figure 5). The model rainfalls were developed on the basis of the BogdanowiczStachy model (Bogdanowicz \& Stachy, 1998):

$$
h_{\max }=1.42 t^{0.33}+\alpha(R, t) \cdot(\ln p)^{0.584},
$$

where: $h_{\max }$ - maximum rainfall depth, $m m ; t$ - rainfall duration time, min.; $\mathrm{p}$ - probability of exceeding rainfall: $p \in(0 ; 0.5] ; \alpha$ - parameter (scale) dependent on the region of Poland and duration time t.
Rain barrels were selected due to the local possibilities, both soil-water conditions as well as the properties of the terrain. The rain barrels consist of just a surface layer that receives runoff captured from a rooftop and has an overflow outlet plus a storage zone with a $100 \%$ void ratio and an underdrain outlet whose flow coefficients are equivalent to those of an orifice (Rossman, 2010). The implementation of variants covering the gathering of water from the rooftops of buildings covers the localization of 234 home tanks in areas developed with single-family homes and terraced housing (Figure 6).

The active storage of a single home tank is taken as $5 \mathrm{~m}^{3}$. The total catchment area covered by the modernization is equal to $14.5 \mathrm{ha}$. The impervious catchment area was estimated at 7 ha. Excess water cannot be infiltrated due to local conditions, so it is directed to the existing sewer system. Retention tanks in the model are represented by closed channels with a rectangular crosssection.

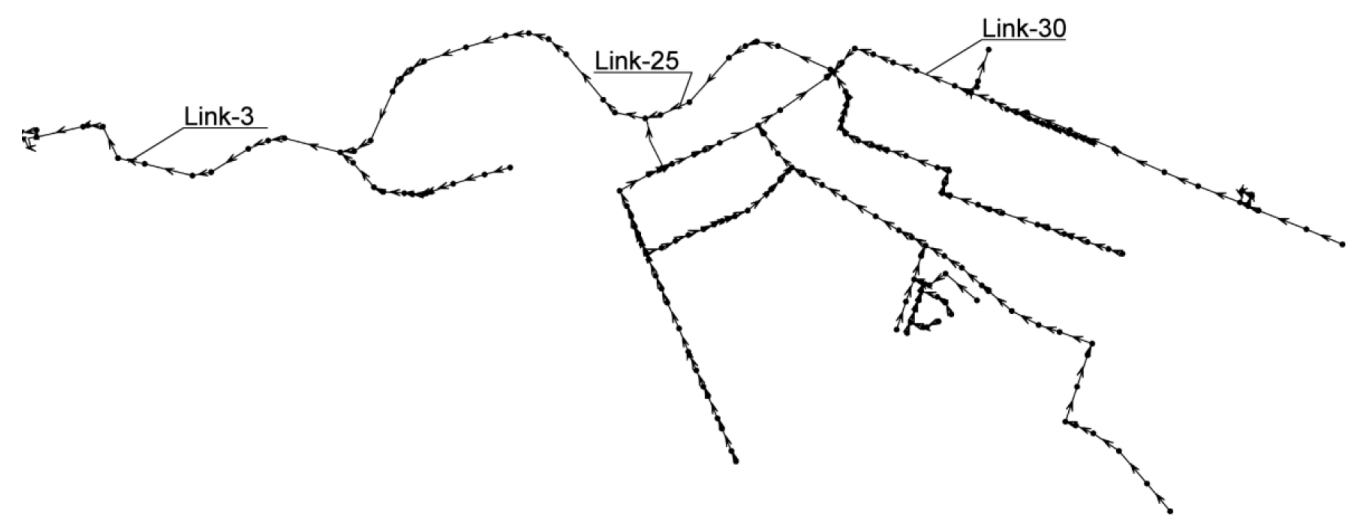

Figure 4. Diagram of modernized stormwater drainage system with the analysed sections marked

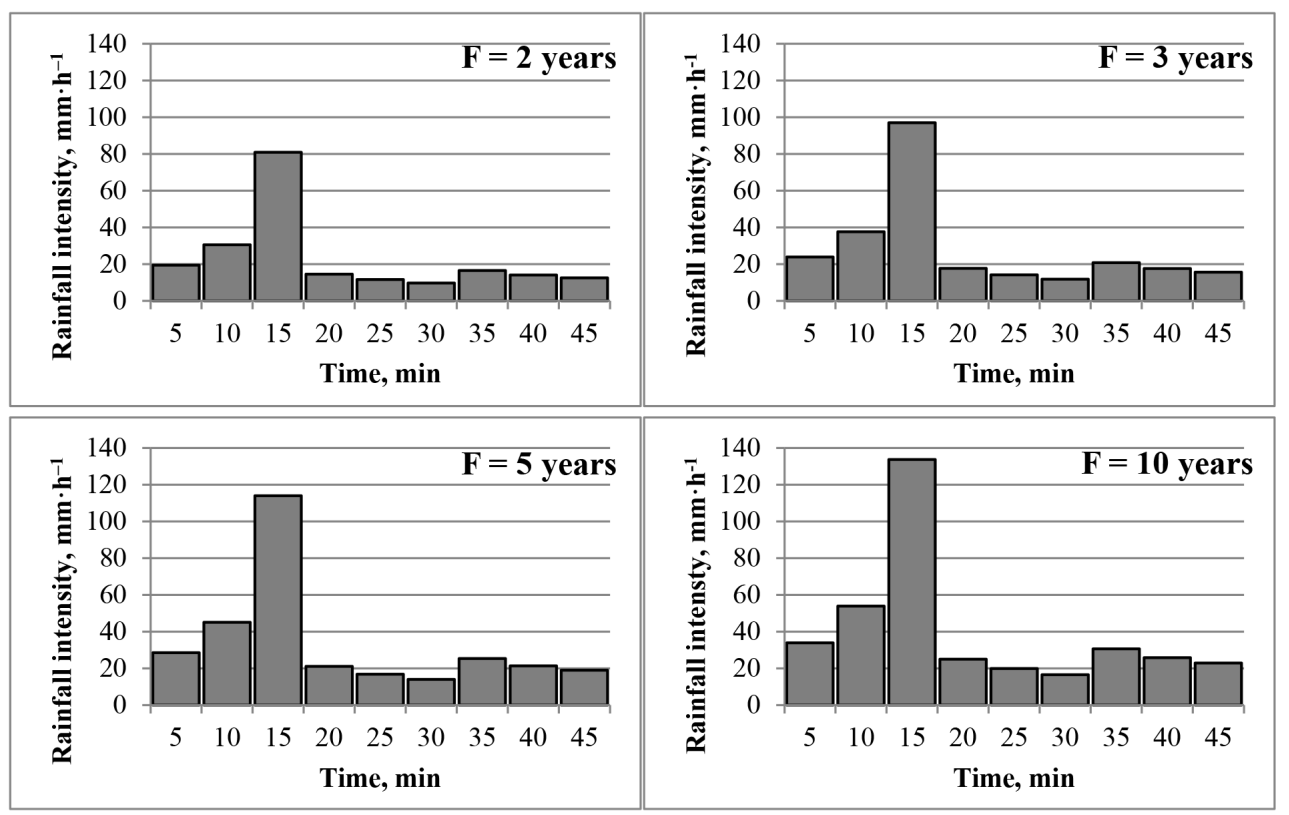

Figure 5. Diagrams of Euler type II model precipitation - duration $45 \mathrm{~m}$

( $\mathrm{F}$ - frequency of occurrence of modelled precipitation) 


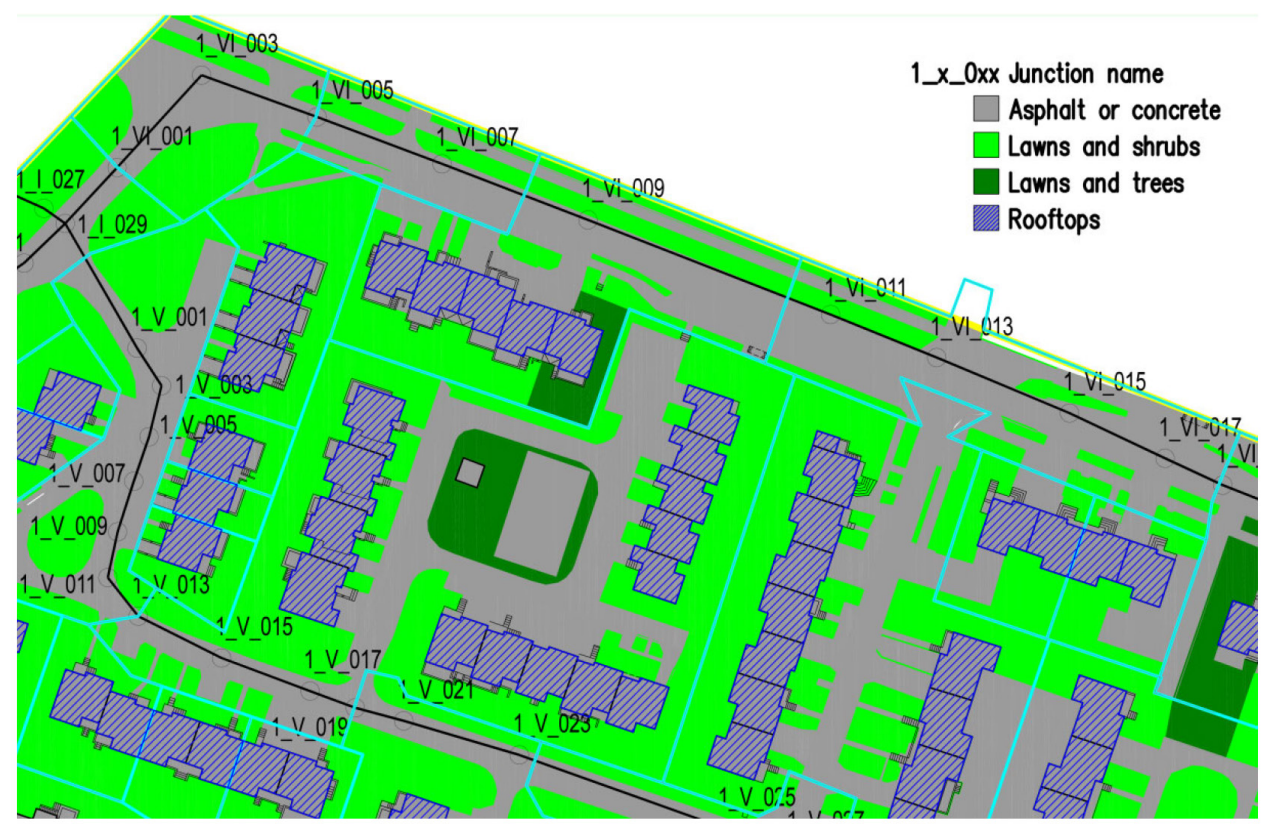

Figure 6 . Areas covered by the system of rainwater collection and utilization within the property

\section{Results and discussion}

The results of simulations are presented in Figures 7, 8, 9 and 10 . The results for segment 30 , located directly on the runoff of the modernized area, have been presented graphically.

In Figure 7, graphs of changes in flow intensity over the duration of the model rainfall have been presented for selected frequencies of the occurrence of rainfall. In Figures 8, 9 and 10, the graphs of changes in the intensity of flows are presented for three of the mentioned calculation variants. Noticeable differences can be observed in the case of rainfalls with a lower intensity and higher probability of occurrence. This confirms the results obtained in diametrically different climatic conditions and another LID technology (Shafique et al., 2018). Under conditions, when the network is not overloaded, the implementation effects are easily identifiable in the analyzed channel (Zhu \& Chen, 2017). The maximum outflow from the analyzed catchment after the use of rain barrels is reduced by 4.5 to 12.0 percent. In the case of simultaneous use of conventional solutions, obtained reduction of 9 to 16 percent of the maximum outflow. Even in the case of such a simple solution as applying rain barrels, it ought to be said that LID should not be treated as a universal solution making it possible to limit peak rainfall runoff and provide full protection against the occurrence of urban flooding. Significant correction of peak temporary flow intensity can be misleading. The course of the phenomena after some time becomes stabilized, and although its course is advantageous after modernization, its differences are significantly smaller.

Figure 11 presents the total volume of rainwater which could not be taken away by the system of channels and escapes onto the surface of the terrain, flooding part of the catchment. It ought to be noticed that the drainage system was not designed adequately to the current needs. Local flooding already occurs in the case of rain at $\mathrm{F}=2$ years, while the application of LID techniques does not cause a

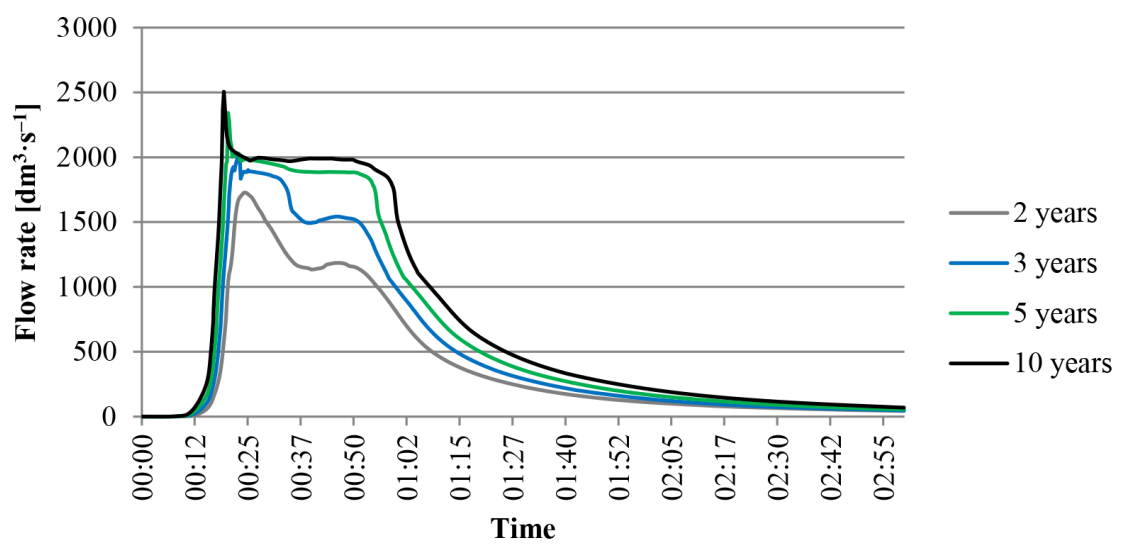

Figure 7. Changes in the intensity of flow through channel Link-30 - existing system prior to modernization 
significant improvement in the conditions. An important change is noticeable after the application of classic retention techniques.

The usefulness of LID in the analyzed catchment is limited by the current state of the catchment. In the case of the frequency of the occurrence of rainfall of 5 and 10 years, a proportional increase in the effectiveness of the operation of home reservoirs does not occur due to the fact that a large amount of rainwater does not reach the channel or is dumped on the surface of the terrain from an overfilled channel. In the case of applying classical solutions, irrelevant of the occurrence of LID, at a rainfall with a frequency of 2 years, local flooding is so insignificant that it can be ignored.

Tables 1, 2 and 3 compile values of the intensity of flow in selected calculation segments obtained based on a

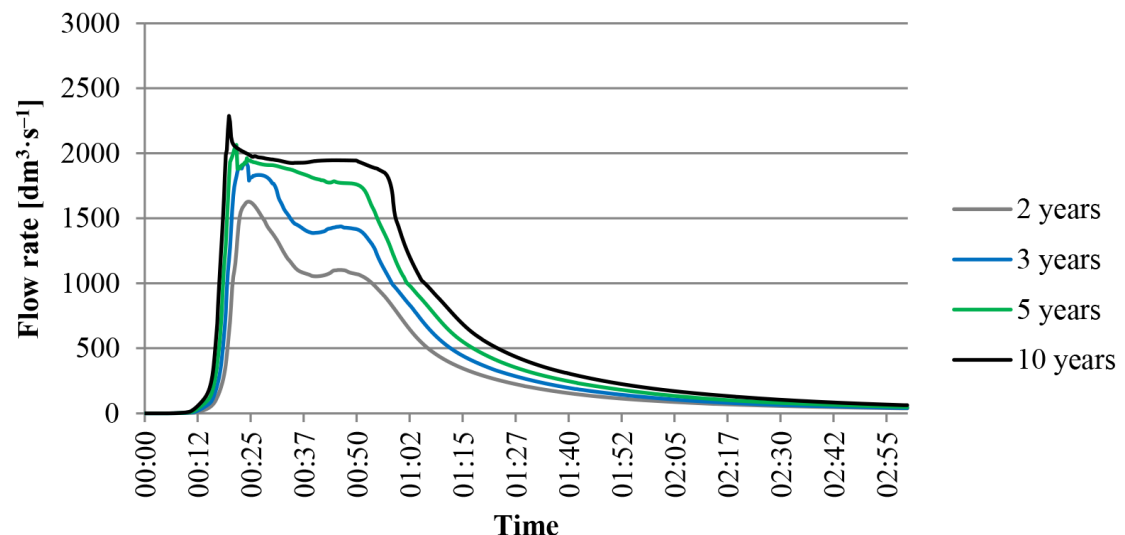

Figure 8. Changes in flow intensity through channel Link-30 - existing system prior to modernization after implementing rain barrels

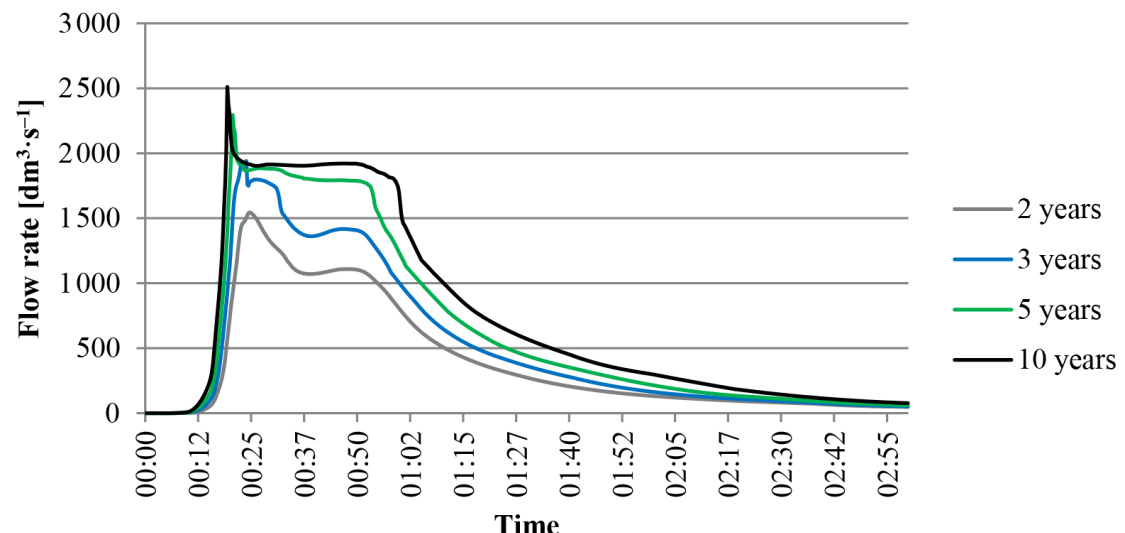

Figure 9. Change in the intensity of flow through channel Link-30 - after the implementation of modernization works

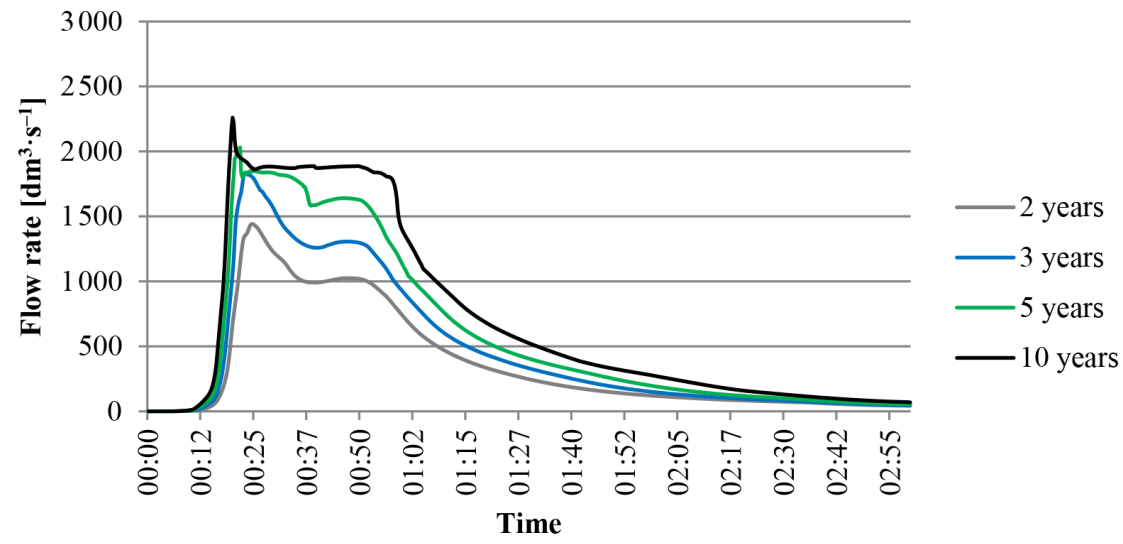

Figure 10. Change in the intensity of flow through channel Link-30 - after implementation of modernization works and implementation of rain barrels 


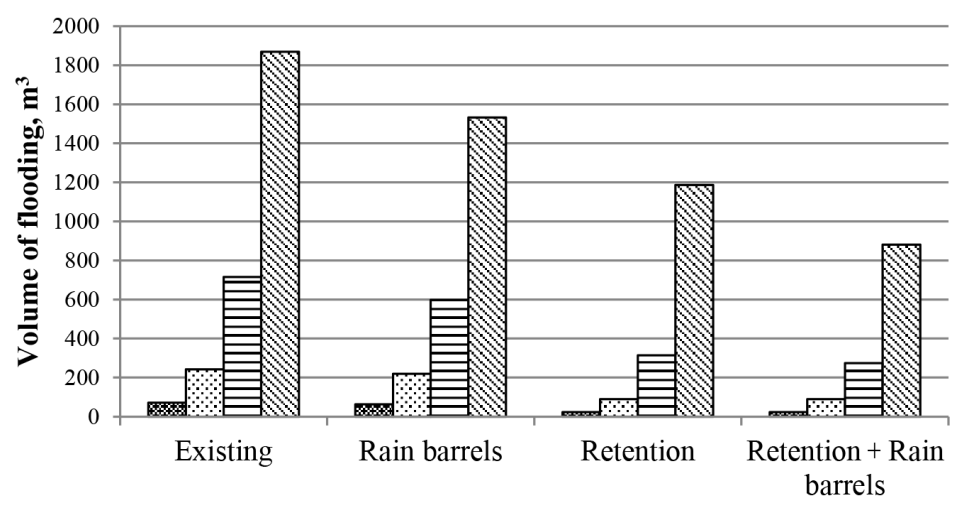

Calculation variant
Rainfall

frequency

ख 2 years

․․ 3 years

曰5 years

Q 10 years

Figure 11. Total volumes of flooding

calibrated model describing the state of the system prior to modernization using the mentioned model rainfalls. A reduction in the intensity of flow after introducing

Table 1. Reduction of flow in section Link-3

\begin{tabular}{|l|c|c|c|c|}
\hline \multicolumn{1}{|c|}{ Link-3 } & $\mathrm{F}=2$ & $\mathrm{~F}=3$ & $\mathrm{~F}=5$ & $\mathrm{~F}=10$ \\
\hline $\begin{array}{l}\text { Existing system, } \\
\mathrm{dm}^{3} \cdot \mathrm{s}^{-1}\end{array}$ & 2016.25 & 2331.69 & 2709.16 & 2857.23 \\
\hline $\begin{array}{l}\text { Variant I - Rain } \\
\text { Barrels, \% }\end{array}$ & 4.1 & 3.5 & 5.6 & 0.4 \\
\hline $\begin{array}{l}\text { Variant II - Detention } \\
\text { tanks, \% }\end{array}$ & 3.3 & -0.9 & 0.0 & -0.1 \\
\hline $\begin{array}{l}\text { Variant III - Detention } \\
\text { tanks and Rain barrels, } \\
\%\end{array}$ & 8.0 & 2.9 & 4.9 & 0.2 \\
\hline
\end{tabular}

Table 2. Reduction of flow in section Link-25

\begin{tabular}{|l|c|c|c|c|}
\hline \multicolumn{1}{|c|}{ Link-25 } & $\mathrm{F}=2$ & $\mathrm{~F}=3$ & $\mathrm{~F}=5$ & $\mathrm{~F}=10$ \\
\hline $\begin{array}{l}\text { Existing system, } \\
\mathrm{dm}^{3} \cdot \mathrm{s}^{-1}\end{array}$ & 1721.34 & 1912.87 & 2195.13 & 2328.11 \\
\hline $\begin{array}{l}\text { Variant I - Rain } \\
\text { Barrels, \% }\end{array}$ & 5.4 & 3.8 & 10.4 & 7.2 \\
\hline $\begin{array}{l}\text { Variant II - Detention } \\
\text { tanks, \% }\end{array}$ & 10.4 & 4.9 & 0.1 & -1.7 \\
\hline $\begin{array}{l}\text { Variant III - Detention } \\
\text { tanks and Rain barrels, } \\
\%\end{array}$ & 16.1 & 9.7 & 15.0 & 2.9 \\
\hline
\end{tabular}

Table 3. Reduction of flow in section Link-30

\begin{tabular}{|l|c|c|c|c|}
\hline \multicolumn{1}{|c|}{ Link-30 } & $\mathrm{F}=2$ & $\mathrm{~F}=3$ & $\mathrm{~F}=5$ & $\mathrm{~F}=10$ \\
\hline $\begin{array}{l}\text { Existing system, } \\
\mathrm{dm}^{3} \cdot \mathrm{s}^{-1}\end{array}$ & 1728.23 & 2013.94 & 2342.54 & 2505.38 \\
\hline $\begin{array}{l}\text { Variant I - Rain } \\
\text { Barrels, \% }\end{array}$ & 5.7 & 4.5 & 11.8 & 8.7 \\
\hline $\begin{array}{l}\text { Variant II - Detention } \\
\text { tanks, \% }\end{array}$ & 10.6 & 3.6 & 2.0 & -0.2 \\
\hline $\begin{array}{l}\text { Variant III - Detention } \\
\text { tanks and Rain barrels, } \\
\%\end{array}$ & 16.5 & 8.8 & 13.3 & 9.8 \\
\hline
\end{tabular}

modernizations described as calculation variants $1 \div 3$ was confronted against base flow intensities. Selected for comparison were the starting segment (Link-30) and end segment (Link-25) of the transit channel between the analyzed area and the western part of the stormwater drainage system with a diameter of $1000 \mathrm{~mm}$ as well as segment located before the retention tank before the outflow to the receiver with a diameter of $1200 \mathrm{~mm}$. Location of the sections is shown in Figure 4.

The obtained results indicate a significant influence of applying LID techniques in the form of home tanks on the maximum intensity of rainwater runoff directly in the drainage channel from modernized catchments. In the case of the channel draining rainwaters from the entire catchment - Link-03 - changes in the flow intensity are significant only at $\mathrm{F}=2$; in the remaining cases, the benefits are not so significant to economically support their implementation. This confirms the results presented in other studies (Seo et al., 2017; Zhu \& Chen, 2017). Zhu and Chen (2017) found that among rainfall intensity, rainfall duration and rainfall peak coefficient, the control effects of LID practices are most affected by rainfall intensity (Shafique et al., 2018). The results obtained for variant I are similar to those presented in the literature. The runoff reduction for the Link-30 cross-section ranges from 4.5 to $11.8 \%$ depending on the rainfall intensity. Ahiableme, Engel, and Chaubey (2013) at various application levels of barrel/cistern and porous pavement found a $2-12 \%$ reduction in runoff for the two analyzed catchments.

The results are important from a practical point of view, especially in the case of existing systems. In the case of newly designed systems, the restrictions are usually smaller and are associated with:

- the possibility of introducing LID solutions, e.g. rain barrels or rain gardens at the design and implementation stage;

- the possibility of correlating project activities in the field of construction works and planned on common parts (urban, common parts of communities, etc.).

This requires fulfillment of certain startup conditions, e.g. (Fletcher et al., 2015): 
- introduction of restrictions on the discharge of storm water to sewage systems in national and local investment implementation conditions (Goulden et al., 2018);

- raising public awareness of the use of rainwater in private areas and in common areas of residential areas (Mahauta \& Andrieub, 2019);

- implementing the financial incentive program as an economic complement to public awareness raising activities.

A different approach should be used for existing systems, where drainage systems are overloaded and even local flooding of land and buildings often occur (Zhu \& Chen, 2017). In this case, various activities should be carried out. Resistance of local society may arise, when the cost of solving the problem is passed on to the residents. The more so, as it has been shown earlier, the results of implementation in home areas are not sufficient in some cases.

The presented analysis does not exhaust the topic of applying LID techniques in existing systems operated in hydraulically and hydrologically unfavorable conditions. It is planned to develop an analysis for a facility located in areas, where it will be possible to use LID based on stormwater infiltration and use LID to reduce the hydraulic load of combined sewage systems (Srishantha \& Rathnayake, 2017).

It is also planned to use field measurements, after implementing at least some of the home tanks using real, measured rainfall data (Ahmed et al., 2017). The minimum target monitoring system will include:

- rain gauge located in the analyzed catchment area;

- 4 measuring stations enabling the measurement of sewage depth or flow rate in channels.

Positive results obtained in the pilot area and limiting the scope of local flooding will allow to convince a larger group of inhabitants to invest in the implementation of LID on their property (Pappalardo \& La Rosa, 2020).

\section{Conclusions}

The results obtained as a effect of the carried out works made it possible to draw the following conclusions:

- reducing flow rate in drainage allows to reduce the volume of local flooding, especially in the case of low rainfall intensity;

- LID may not be effective for systems overloaded with runoff from relatively low intense rainfalls;

- in the case of intensive rainfall with a frequency of 5 and 10 years, the use of LID is definitely more effective than classic solutions. This confirms the results obtained by Damodaram et al. (2010);

- the application of LID and classical means of delaying rainfall runoff significantly influences the protection of the receiver by decreasing the flow rate in channels, which makes it possible to decrease the process of washing out contaminants collected in the channel network;
- the application of LID should not be treated as a universal solution enabling the urban flooding or local flooding of terrain or buildings to be avoided, especially in the case of channel system designed and constructed under assumptions not accounting for climate changes, the degree of sealing urban catchments, etc.;

- LID, and especially water harvesting ought to be implemented synchronically with classical solutions such as: retention in tanks, retention in channels or introducing elements steering the flow of rainwater. This confirms the results obtained by Damodaram et al. (2010), Liu et al. (2015), Xie et al. (2017) and Alves et al. (2018);

- the gathering of water ought to be planned in a comprehensive manner, that is it ought to be implemented in connection with all buildings in the catchment (La Rosa \& Pappalardo, 2019; Anim et al., 2019);

- LID ought to be, so long as it is possible, planned at the stage of planning the development and infrastructure; following the completion of the investment, the possibilities of implementation fall at a drastic rate, and usually require specific solutions necessitating their application or financial encouragement changing the attitudes of real estate owners.

To sum up, it can be claimed that LID techniques are a significant step on the road to simulating the natural water cycle in a catchment in urbanized areas. The problem is significant primarily due to the increasing impact of climate change on the frequency and intensity of extreme rainfall (Srishantha, \& Rathnayake, 2017). The benefits of applying such solutions ought to be examined not only in the economic aspect, but also, above all - should be supported by hydraulic analysis. The other problem to solve is, above all, raising the social awareness of real estate owners and solutions at the level of local governments (Kim \& An, 2017; Chang et al., 2018). Forcing investors, including commercial investors such as development companies, to establish a proper infrastructure in developed areas will make it possible to avoid the implementation of irrational, temporary interim solutions for solving problems connected with local flooding. The investment costs, in this case, can be much lower than in cases when works require damage to and re-creation of existing infrastructure arousing doubts and even significant resistance connected with short-term impediments for inhabitants. Interim solving of problems, without global visions and analyses on a greater area, which can also give a negative effect in the form of the transfer of phenomena to neighboring catchments, which can, in extreme cases, result in conflicts between owners and even court cases.

The optimal solution is acceptance by a local government unit - commune or city - of guidelines accounting for, among others, LID and consequential enforcement at the stage of issuing building permits or supervision at the time of realizing the investment. 


\section{References}

Ahiableme, L. M., Engel, B. A., \& Chaubey, I. (2013). Effectiveness of low impact development practices in two urbanized watersheds: Retrofitting with rain barrel/cistern and porous pavement. Journal of Environmental Management, 119, 151161. https://doi.org/10.1016/j.jenvman.2013.01.019

Ahmed, K., Chung, E. S., Song, J. Y., \& Shahid, S. (2017). Effective design and planning specification of low impact development practices using Water Management Analysis Module (WMAM): Case of Malaysia. Water, 9(3). https://doi.org/10.3390/w9030173

Alves, A., Gersonius, B., Sanchez, A., Vojinovic, Z., \& Kapelan, K. (2018). Multi-criteria approach for selection of green and grey infrastructure to reduce flood risk and increase co-benefits. Water Resources Management, 32(7), 2505-2522. https://doi.org/10.1007/s11269-018-1943-3

Anim, D. O., Fletcher, T. D., Pasternack, G. B., Vietz, G. J., Duncan, H. P., \& Burns, M. J. (2019). Can catchment-scale urban stormwater management measures benefit the stream hydraulic environment? Journal of Environmental Management, 233, 1-11. https://doi.org/10.1016/j.jenvman.2018.12.023

Bąk, J. (2018). Modelling the relationship between LID practices and the runoff of rainwater through the example of rainfall data for Krakow. E3S Web of Conferences, 45(8). https://doi.org/10.1051/e3sconf/20184500008

Berndtsson, R., Becker, P., Persson, A., Aspegren, H., Haghighatafshar, S., Jönsson, K., Larsson, R., Mobini, S., Mottaghi, M., Nilsson, J., Nordström, J., Pilesjö, P., Scholz, M., Sternudd, C., Sörensen, J., \& Tussupova, K. (2019). Drivers of changing urban flood risk: A framework for action. Journal of Environmental Management 240, 47-56. https://doi.org/10.1016/j.jenvman.2019.03.094

Bogdanowicz, E., \& Stachý, J. (1998). Maksymalne opady deszczu w Polsce. Charakterystyki projektowe. Warszawa: Instytut Meteorologii i Gospodarki Wodnej (in Polish).

Bosley, II, E. K. (2008). Hydrologic evaluation of low impact development using a continuous, spatially-distributed model (MA thesis). Virginia Polytechnic Institute and State University, Blacksburg. https://www.researchgate.net/publication/265824795_Hydrologic_Evaluation_of_Low_Impact_ Development_Using_a_Continuous_Spatially-Distributed_ Model_in_Memoriam

Chang, N. B., Lu, J. W., Chui, T. F. M., \& Hartshorn, N. (2018). Global policy analysis of low impact development for stormwater management in urban regions. Land Use Policy, 70, 368-383. https://doi.org/10.1016/j.landusepol.2017.11.024

Coffman, L. (1999). Low-impact development design strategies: An integrated design approach (Report EPA 841-B-00-003). U.S. Environmental Protection Agency, Washington, D.C., USA. https://nepis.epa.gov/Exe/ZyPURL.cgi?Dockey=20004JX4.txt

Damodaram, C., Giacomoni, M. H., Khedun, C. P., Holmes, H., Ryan, A., Saour, Q., \& Zechman, E. M. (2010). Simulation of combined best management practices and low impact development for sustainable stormwater management. Journal of the American Water Resources Association, 46(5), 907-918. https://doi.org/10.1111/j.1752-1688.2010.00462.x

Eckart, K., McPhee, Z., \& Bolisetti, T. (2017). Performance and implementation of low impact development - A review. Science of the Environment, 607-608, 413-432.

https://doi.org/10.1016/j.scitotenv.2017.06.254

Eckart, K., McPhee, Z., \& Bolisetti, T. (2018). Multiobjective optimization of low impact development stormwater controls. Journal of Hydrology, 562, 564-576.

https://doi.org/10.1016/j.jhydrol.2018.04.068
Fletcher, T. D., Shuster, W., Hunt, W. F., Ashley, R., Butler, D., Arthur, S., Trowsdale, S., Barraud, S., Semadeni-Davies, A., Bertrand-Krajewski, J. L., Mikkelsen, P. S., Rivard, G., Uhl, M., Dagenais, D., \& Viklander, M. (2015). SUDS, LID, BMPs, WSUD and more - The evolution and application of terminology surrounding urban drainage. Urban Water Journal, 12(7), 525-542. https://doi.org/10.1080/1573062X.2014.916314

Goulden, S., Portman, M. E., Carmon, N., \& Alon-Mozes, T. (2018). From conventional drainage to sustainable stormwater management: Beyond the technical challenges. Journal of Environmental Management, 219, 37-45.

https://doi.org/10.1016/j.jenvman.2018.04.066

Granata, F., Gargano, R., \& de Marinis, G. (2016). Support vector regression for rainfall-runoff modeling in urban drainage: $A$ comparison with the EPA's storm water management model. Water, 8(3), 69. https://doi.org/10.3390/w8030069

Huang, C. L., Hsu, N. S., Liu, H. J., \& Huang, Y. H. (2018). Optimization of low impact development layout designs for megacity flood mitigation. Journal of Hydrology, 564, 542-558. https://doi.org/10.1016/j.jhydrol.2018.07.044

Jia, H., Lu, Y., Yu, S. L., \& Chen, Y. (2012). Planning of LIDBMPs for urban runoff control: The case of Beijing Olympic Village. Separation and Purification Technology, 84, 112-119. https://doi.org/10.1016/j.seppur.2011.04.026

Joksimovic, D., \& Alam, Z. (2014). Cost efficiency of Low Impact Development (LID) stormwater management practices. Procedia Engineering, 89, 734-741.

https://doi.org/10.1016/j.proeng.2014.11.501

Kim, S., \& An, K. (2017). Exploring psychological and aesthetic approaches of bio-retention facilities in the urban open space. Sustainability, 9(11). https://doi.org/10.3390/su9112067

Kong, F., Ban, Y., Yin, H., James, P., \& Dronova, I. (2017). Modeling stormwater management at the city district level in response to changes in land use and low impact development. Environmental Modelling \& Software, 95, 132-142. https://doi.org/10.1016/j.envsoft.2017.06.021

Krebs, G., Kokkonen, T., Valtanen, M., Setälä, H., \& Koivusalo, H. (2014). Spatial resolution considerations for urban hydrological modelling. Journal of Hydrology, 512, 482-497. https://doi.org/10.1016/j.jhydrol.2014.03.013

La Rosa, D., \& Pappalardo, V. (2019). Planning for spatial equity - A performance based approach for sustainable urban drainage systems. Sustainable Cities and Society, 53, 101885. https://doi.org/10.1016/j.scs.2019.101885

Li, Q., Wang, F., Yu, Y., Huang, Z., Li, M., \& Guan, Y. (2019). Comprehensive performance evaluation of LID practices for the sponge city construction: A case study in Guangxi, China. Journal of Environmental Management, 231, 10-20. https://doi.org/10.1016/j.jenvman.2018.10.024

Liu, Y., Bralts, V. F., \& Engel, B. A. (2015). Evaluating the effectiveness of management practices on hydrology and water quality at watershed scale with a rainfall-runoff model. Science of the Total Environment, 511, 298-308. https://doi.org/10.1016/j.scitotenv.2014.12.077

Mahauta, H., \& Andrieub, H. (2019). Relative influence of urban-development strategies and water management on mixed (separated and combined) sewer overflows in the context of climate change and population growth: A case study in Nantes. Sustainable Cities and Society, 44, 171-182. https://doi.org/10.1016/j.scs.2018.09.012

Mao, X., Jia, H., \& Yu, S. L. (2017). Assessing the ecological benefits of aggregate LID-BMPs through modelling. Ecological Modelling, 353, 139-149.

https://doi.org/10.1016/j.ecolmodel.2016.10.018 
Mrowiec, M., \& Sobczyk, M. (2014). Ecological management of rainwaters - green roofs. Water-Environment-Rural Areas, 48, 53-61.

Nowogoński, I., \& Ogiołda, E. (2018). Verification of the combined sewage system simulation model based on the example of the city of Głogów. E3S Web of Conferences, 45, 00058. https://doi.org/10.1051/e3sconf/20184500058

Palla, A., \& Gnecco, I. (2015). Hydrologic modeling of Low Impact Development systems at the urban catchment scale. Journal of Hydrology, 528, 361-368. https://doi.org/10.1016/j.jhydrol.2015.06.050

Pappalardo, V., \& La Rosa, D. (2020). Policies for sustainable drainage systems in urban contexts within performancebased planning approaches. Sustainable Cities and Society, 52, 101830. https://doi.org/10.1016/j.scs.2019.101830

Rossman, L. A. (2010). Modeling Low Impact Development alternatives with SWMM. Journal of Water Management Modeling, 18, 167-182. https://doi.org/10.14796/JWMM.R236-11

Rossman, L. A. (2015). Storm water management model user's manual version 5.1 (EPA/600/R-14/413b). US EPA National Risk Management Research Laboratory, Cincinnati, Ohio, USA.

Seo, M., Jaber, F., Srinivasan, R., \& Jeong, J. (2017). Evaluating the impact of Low Impact Development (LID) practices on water quantity and quality under different development designs using SWAT. Water, 9(3), 193. https://doi.org/10.3390/w9030193

Shafique, M., Kim, R., \& Kyung-Ho, K. (2018). Green roof for stormwater management in a highly urbanized area: The case of Seoul, Korea. Sustainability, 10(3), 584.

https://doi.org/10.3390/su10030584
Shuttleworth, A. B., Nnadi, E. O., Mbanaso, F. U., Coupe, S. J., Voeten, J. G. W. F., \& Newman, A. P. (2017). Applications of SuDS techniques in harvesting stormwater for landscape irrigation purposes: Issues and considerations. In Current Perspective on irrigation and drainage. IntechOpen. https://doi.org/10.5772/67041

Srishantha, U., \& Rathnayake, U. (2017). Sustainable urban drainage systems (SUDS) - what it is and where do we stand today? Engineering and Applied Science Research, 44(4), 235241. https://doi.org/10.14456/easr.2017.36

Woods-Ballard, B., Wilson, S., Udale-Clarke, H., Illman, S., Scott, T., Ashley, R., \& Kellagher, R. (2015). The SuDS manual. CIRIA, Griffin Court, 15 Long Lane. London.

Xie, J., Chen, H., Liao, Z., Gu, X., Zhu, D., \& Zhang, J. (2017). An integrated assessment of urban flooding mitigation strategies for robust decision making. Environmental Modelling \& Software, 95, 143-155. https://doi.org/10.1016/j.envsoft.2017.06.027

Zhu, Z., \& Chen, X. (2017). Evaluating the effects of low impact development practices on urban flooding under different rainfall intensities. Water, 9(7), 548. https://doi.org/10.3390/w9070548

Zhu, Z., Chen, Z., Chen, X., \& Yu, G. (2019). An assessment of the hydrologic effectiveness of low impact development (LID) practices for managing runoff with different objectives. Journal of Environmental Management, 231, 504-514. https://doi.org/10.1016/j.jenvman.2018.10.046

Zimmer, C. A., Heathcote, I. W., Whiteley, H. R., \& Schroeter, H. (2007). Low Impact Development practices for stormwater implications for urban hydrology. Canadian Water Resources Journal, 32(3), 193-212. https://doi.org/10.4296/cwrj3203193 